\title{
Materyal Geliştirmede Ses Kayıt ve Düzenleme Programlarının Kullanımına Yönelik Öğrenci Görüşleri*
}

\section{Student Opinions on the Use of Digital Audio Workstation Software in Material Development}

\section{Erkan Demirtaş}

Doktora öğrencisi, Gazi Üniversitesi, Eğitim Bilimleri Enstitüsü, Müzik Eğitimi Bölümü email: erkandemirts@gmail.com DORCID ID: https://orcid.org/0000-0002-4357-6697

\section{Türker Eroğlu}

Prof. Dr., Gazi Üniversitesi, Gazi Eğitim Fakültesi, Müzik Eğitimi Anabilim Dalı email: turkereroglu@gazi.edu.tr (DORCID ID: https://orcid.org/0000-0002-5943-209X

* Bu çalışma "Müzik Öğretmeni Adaylarının Öğretim Materyali Geliştirme Aracı Olarak Ses Kayıt ve Düzenleme Programlarının Kullanılmasına Yönelik Görüșleri” isimli yüksek lisans tezinden türetilmiștir.

$\checkmark$ iThenticate" Bu makale bilimsel etik ve kurallara uygun hazırlanmış ve intihal incelemesinden geçirilmiştir.

Atıf (APA 6)/To cite this article

Demirtaş, E., \& Eroğlu, T. (2020). Materyal geliştirmede ses kayıt ve düzenleme programlarının kullanımına yönelik öğrenci görüşleri. Atatürk Üniversitesi Güzel Sanatlar Enstitüsü Dergisi, 26(Müzik Özel Sayıs1), 314-326. doi: https://doi.org/10.35247/ataunigsed.620641

Makale Gönderim Tarihi/Received: 16/09/2019

Makale Kabul Tarihi/Accepted: 11/03/2020

Makale Yayın Tarihi/Published: 25/03/2020

Research Article / Araștırma Makalesi

\section{Öz}

$\mathrm{Bu}$ araștırmada, müzik öğretmenliği bölümü öğrencilerinin se kayıt ve düzenleme programlarının öğretim materyali geliştirme aracı olarak kullanılmasına yönelik görüşlerinin incelenmesi amaçlanmıştır. Tarama modelinin kullanıldı̆̆ bu araştırmada araştırmacılar tarafindan geliștirilen "ses kayıt ve düzenleme programlarının öğretim materyali gelistirme aracı olarak kullanılması" ölçeği veri toplama aracı olarak kullanılmıştır. Ölçekle ilgili geçerlilik ve güvenirlik çalıșmaları yapıldıktan sonra 282 müzik eğitimi anabilim dalı öğrencisine ölçeğin uygulaması yapılmıştır. Araştırma sonucunda: müzik öğretmenliği bölümü öğrencilerinin ses kayıt ve düzenleme programlarının öğretim materyali geliştirme aracı olarak kullanılmasına yönelik görüșlerinin olumlu yönde olduğu; cinsiyet değişkenine göre görüşlerde bir farklılık oluşmadığı; sınıf düzeyi değişkenine göre yapılan incelemede dördüncü ve üçüncü sınıflara devam eden öğrencilerin, ikinci ve birinci sınıflara devam eden öğrencilere göre daha olumlu bir görüşe sahip oldukları; bireysel çalgı türü değișkenine göre yapılan incelemede Batı Müziği enstrümanı çalan öğrencilerin, Türk Müziği enstrümanı çalan öğrencilere göre daha olumlu bir görüșe sahip oldukları; en sevdikleri müzik türü değișkenine göre yapılan incelemede Popüler Müziği en sevdiği müzik türü olarak belirten öğrencilerin, diğer müzik türlerine göre daha olumlu bir görüs içinde oldukları sonuçlarına varılmıştır.

Anahtar kelimeler: Müzik Yazılımları, Müzik Eğitimi, Eğitim Teknolojisi

\begin{abstract}
The aim of this research is to examine and analyze the ideas of music teacher candidates for the use of digital audio workstation software as a tool for developing teaching material. In this research on the screening model, "the use of digital audio workstation software as a tool for developing teaching material" as a scale was used as a data collection tool which is developed by the researchers. After the studies of validity and reliability were performed, a questionnaire application was applied to 282 music teacher candidates. As a result of the research, it was found that the views of music teacher candidates on the use of digital audio workstation software as a tool for developing teaching material are positive; the views do not vary according to the gender factor; fourth and third grade students in the examination according to the class levels have a more positive judgment than the second and first grade students; the students who played the Western Music instrument in the examinations made according to the types of the individual instruments have a more positive judgment than the students who played the Turkish Music instruments; the students who stated that Popular Music as their favorite music genre according to the most popular music genres are in a more positive view than the other music genres.
\end{abstract}

Keywords: Music Software, Music Education, Educational Technology

\section{Giriş}

Bilim ve teknoloji alanlarında yaşanan hızlı gelişmelerle birlikte, küreselleşme süreci hızlanmış, ülkeler ve kültürler arası etkileşim artmış, toplumların yaşam standartları yükselmiş, bu doğrultuda bireylerin ve dolayısıyla toplumların yapı ve ihtiyaçları değişmiştir (Çelik \& Şendağ, 2013, s. 10). Değişen ihtiyaçlar doğrultusunda teknolojik gelişmelerin en çok etkilediği alanların başında eğitim gelmektedir. Eğitimde modern teknolojilerin kullanılması hem öğretmen hem de öğrencilerin performanslarının artmasına katkı sağlamaktadır (Aslan Efe \& Baysal, 2017).

Öğretim kavramı, Kalelioğlu (2015) tarafından "öğrenenlerin bilgi, beceri, tutum ve yetenek kazanması için deneyimlerinin amaçlı olarak düzenlenmesi” (s. 2); Kaya (2006) tarafından ise "bilgi ve çevrenin öğrenmeyi 
oluşturmak için düzenlenmesi” (s. 4) olarak açıklanmaktadır. Bu doğrultuda müzik öğretimi ise öğreneni, belirlenen hedef doğrultusunda hazırlanmış olan çevrenin öğeleriyle etkileştirerek, davranışlarında müzikle ilgili istenen değişimleri gerçekleştirme süreci olarak açıklanabilir (Uçan, 1997, s. 67). Müzik alanı, yapısı gereği görsel işitsel ve icrasal becerilerin uyumlu bir şekilde bir arada bulunduğu bir alandır. Bu sebeple materyal kullanımında teknoloji desteğinden önemli derecede yararlanılması gereken alanlardan birisidir (Yengin, 2014, s. 14). Öğretmenin öğrencilerinin beklentilerini karşılayabilmek için bilişim teknolojileri alanında yeterli seviyeye gelerek güncel gelişmeleri takip etmesi gerekmektedir (Hırça \& Genç, 2012, s. 253).

Teknolojik gelişmeleri ve yenilikleri takip eden müzik öğretmeninin bu sayede, sınıf içinde kullanabileceği materyal çeşitliliğini ve kalitesini önemli derecede artırabileceği (Lewis'den aktaran Çakırer, 2002, s. 11); öğrencilerin ilgisini çeken ve böylece merak ederek keşfederek öğrenmelerini sağlayacak materyaller geliştirebileceği; sadece tekrar eden veya dinleyen değil, müzikal etkinliklere etkin şekilde katılan yaratıcı öğrenciler oluşturmasına destek olabilecek materyaller tasarlayabileceği söylenebilir.

Bireysel bilgisayarların ortaya çıkışı, MIDI (Musical Instrument Digital Interface) yazılım ve donanım protokolünün icadı, elektronik müzik enstrümanlarının yaygınlaşması, yazılım alanındaki ilerlemeler ve internet devrimiyle beraber müzik sınıfları içerisinde kullanılabilecek materyal çeşitliliği tarihte hiç olmadığı kadar artmıştır (Watson, 2011, s. 3).

Alanyazın incelendiğinde müzik eğitiminde teknoloji kullanımına yönelik farklı araştırmalar yürütüldüğü görülmektedir. Juntunen, Ruokonen \& Ruismäki (2015), başlangıç seviyesinde olan 10 yaylı enstrüman öğrencisiyle yaptıkları çalışmada, nota yazım programı kullanarak öğrencilerin kullanabilecekleri eşlik materyali hazırlamışlardır. Araştırmada nicel araştırma yöntemi tercih edilmiş ve deney uygulaması yapılmıştır. Çalışma grubundaki 6 öğrenciye hazırlanan materyal ile, 4 öğrenciye ise materyal olmaksızın aynı eser çalıștırılmıș ve özellikle doğaçlama pasajlarına odaklanılmıştır. Araştırma sonucunda nota yazım programıyla hazırlanan eşlik materyalini kullanan grubun diğer gruba göre daha hızlı öğrendiği, özellikle akıcılık, konsantrasyon, çalarken keyif alma başlıklarında fark olduğu sonuçlarına varmışlardır. Wise, Greenwood ve Davis (2011), yarı yapılandırılmış görüşme formu, anket ve gözlem araçlarını kullanarak dört farklı okulda çalışan dokuz müzik öğretmeniyle, müzik derslerinde teknoloji kullanma durumlarının incelendiği bir çalışma yürütmüşlerdir. Araştırma sonucunda öğretmenlerin hepsinin derslerinde bilişim teknolojilerini kullandıkları, "Sibelius" nota yazım programını, "GarageBand" ses kayıt ve düzenleme programının ve "Music Age" müzik teorisi programını aktif olarak kullandıklarını, düzenli olarak müzik oluşturmak için bilişim teknolojilerini kullandıklarını tespit etmişlerdir. Lehimler \& Şengül (2014), deneysel yöntemi kullandıkları çalışmalarında, nota yazım programı kullanarak hazırladıkları materyalin piyano öğrencileri üzerindeki etkisini ölçmüşlerdir. Araştırma sonucunda, hazırlanan teknolojik materyalin piyano eğitiminde normal öğretim yöntemine göre yaklaşık iki buçuk katı oranında daha fazla katkı sağladığı sonucuna varmışlardır. Rowe, Triantafyllaki \& Anagnostopoulou (2015) 19 piyano öğrencisi ile yürüttükleri çalışmalarında öğrencilerin doğaçlama becerilerini geliştirmek için altı hafta boyunca MIROR isimli interaktif bir doğaçlama yazılımı kullanmışlardır. Araştırma sonucunda kullanılan yazılımın müzikal olarak keşfetme ve doğaçlama yeteneğini geliştirdiğini sonuçlarına varmışlardır.

\subsection{Ses Kayıt ve Düzenleme Programları}

Müzik alanı teknolojik ilerlemelerden önemli derecede etkilenmiş ve buna bağlı olarak da birçok gelişme ve yenilik yaşamıştır. Müziğin dinleme aşaması haricinde, amatör ya da profesyonel olarak müzikle ilgilenenler için birçok yazılım üretilmiştir. Yeni gelişmelerle beraber çeşitleri ve sayıları artmaya devam etmektedir. "Müzik yapımını tamamen değiştiren en önemli gelişmelerden birisi de 1983 yılında MIDI'nin bulunmasıdır” (Önen, 2013, s. 251). Bir çeşit dijital dil olan MIDI, yazılım ve donanımlar arasındaki iletişimi sağlar (Tarikci, 2015, s. 104). MIDI desteğiyle tek bir kişi bile bir parçayı yazıp, düzenleyip çalma imkanına kavuşmuştur. "MIDI ses verilerini iletmez, enstrümanların hangi notaları çalacağı, hangi seslerin kullanılacağı, ne zaman ve nasıl çalınacağı, temposu, cihazlar arasında senkronizasyon, program değişiklikleri gibi bazı değişkenlere ilişkin sayısal bilgileri yazılım ve donanımlar arasında aktarılmasını sağlar" (Önen, 2013, s. 252). MIDI teknolojisi, kullanımda sağladı̆̆ avantajlar sayesinde farklı ihtiyaçlara cevap verebilecek seviyede müzik yazılımının üretilmesinde önemli bir rol oynamıştır. Özellikle mobil teknolojilerin yaygınlaşmasının ardından, bu cihazlara yönelik geliştirilen programlarla müzik yazılımlarının çeşitliliği ve işlevselliğinin önemli derecede arttığı söylenebilir. Bilgisayar sisteminde yapılabilen birçok işlem artık mobil cihaz uygulamalarıyla da yapılabilmektedir. Bu sebeple bu çalışmada kullanılan müzik yazılımları ifadesi ile hem bilgisayar sistemleri hem de mobil uygulamalar kastedilmektedir. Kullanımda olan müzik yazılımları genel olarak incelendiğinde;

- Müzik eğitimi programları: Müzik teorisi, işitme eğitimi, çalgı eğitimi, şan eğitimi gibi alanlar için geliştirilen programlar,

- Ses kayıt ve düzenleme programları: Temelde müzik oluşturma, düzenleme gibi işlemler için geliştirilen programlar,

- Nota yazım programları: Nota yazmak için geliştirilen programlar, 
- Yardımcı programlar: Metronom, akort, efekt, amfi, sanal enstrüman, ses kaydedici gibi özellikler için geliştirilen programlar olarak sınıflandırılabilir.

Gelişen teknolojinin müzikteki yansımalarının en önemli parçalarından olan ses kayıt ve düzenleme programları, müzik oluşturmada sağladıkları kolaylıklar ve zengin içerikleriyle vazgeçilmez yazılımlar haline gelmişlerdir. Bireysel kullanımdan, profesyonel seviyeye kadar her aşamadaki ihtiyaca cevap verebilen bu yazılımların müzisyenler arasındaki kullanımları gittikçe yaygınlaşmaktadır.

Tarihte ses kayıt işlemleri 1800'lü yıllarda bir silindir üzerine akustik titreşimleri geçirebilen bir cihazla başlamış ve daha sonra birçok aşamadan geçmiştir. 1877'de Thomas Edison'un geliştirdiği ses dalgalarını alüminyum folyo sarılı bir silindir üzerine kaydedebilen “phonograph”, 1889'da Valdeman Poulsen'in geliştirdiği ilk manyetik bant kaydının yapıldığı "Telegraphon", 1931'de Pfleumer ve AEG tarafından üretilen ilk manyetik bant kayıt cihazı bu aşamaların ilkleridir. Teknoloji ile paralel gelişen kayıt sistemlerinde, 1980'lerin ortasına kadar analog kayıt cihazları daha sonra ise dijital kayıt cihazları kullanılmaya başlanmıştır. 2000'li yıllara gelindiğinde genel olarak bantlı sistemler yerini hard disk kayıt sistemlerine bırakmıştır. Hard disk kayıt sistemleri, diskin herhangi bir yerindeki veriye anında ulaşma özelliği, ileri geri sarma, kopyala-yapıştır gibi düzenleme kolaylıkları, kayıp riskinin az olması, daha sağlıklı saklama gibi özellikleriyle bantla çalışan analog ve dijital kayıt cihazlarına göre büyük avantajlar getirmiştir (Önen, 2013, s. 147-148).

Hard disk kayıt sistemleri farklı şekillerde görülebilmektedir. En yaygın kullanılanı bilgisayar tabanlı çalışan yazılım ve donanım karışımı sistemlerdir. "Bu sistemlere DAW (Digital Audio Workstation) adı verilmektedir" (Önen, 2013, s. 164). Türkçede "dijital ses çalışma istasyonu” (Önen, 2013, s. 164), "dijital ses atölyesi” (Tarikci, 2015, s. 123), "kanal kayıt ve ses düzenleme programları" (Koldemir, 2008, s. 21), "ses kayıt ve düzenleme programları" (Yengin, 2014, s. 22) gibi farklı şekillerde çevrilerek kullanıldı̆̆ı tespit edilmiştir. Bu çalışmada "ses kayıt ve düzenleme programları" ifadesi tercih edilmiştir.

Ses kayıt ve düzenleme programları; “çok kanallı kayıt yapabilen; yapılan kayıtlar üzerinde düzenleme (edit) yapıp sinyal işleme, miks ${ }^{1}$ ve mastering ${ }^{2}$ olanakları sağlayan yazılımlar" (Tarikci, 2015, s. 124) ya da "bilgisayar tabanlı olarak çalışan yazılım ve donanım konfigürasyonundan oluşan hard disk kayıt sistemlerine verilen isim” (Önen, 2013, s. 383) olarak açıklanabilir.

Bazı kaynaklarda sequencer ifadesiyle de karşılaşılmaktadır. Sequencer, "performans, kontrol, zamanlama, tempo, tempo değişiklikleri, parçanın başı ve sonu ve diğer tüm MIDI verilerini kaydeden, daha sonra bu verilerin kullanıcı tarafından edit edilmesini sağlayan cihaz veya yazılımdır" (Önen, 2013, s. 398). Bu tanımlamadan sequencer cihaz veya yazılımlarının tamamen MIDI ile ilgili olduğu anlaşılmaktadır. Günümüzde "DAW" olarak adlandırılan bütün ses kayıt ve düzenleme programlarının içinde sequencer bulunmaktadır.

Ses kayıt ve düzenleme programlarının genel özellikleri şöyle sıralanabilir;

- Ses Kaydı (Audio Recording): İsteğe ve yapılacak işin seviyesine göre en basit dahili mikrofondan en donanımlı stüdyoların seviyesine kadar müziğin her seviyesinde her sesin kaydı yapılabilir.

- Ses Düzenleme (Audio Editing): Yapılmış olan veya başka ortamlardan aktarılan ses kaydı üzerinde her türlü kesme, birleştirme, hız ayarı, perde/ton değiştirme gibi düzenleme olanağına imkan verilmektedir.

- Çok Kanallı Kayıt (Multitrack Recording): Ses kayıt ve düzenleme programlarının temel işlevi çok kanallı kayıt yapabilmesidir. Makara bantlara kayıt yapıldığı dönemlerde kayıt kapasitesi sınırlıydı fakat günümüzde bilgisayarların işlemci ve sabit sürücü kapasitesi oranında çok kanallı kayıt yapılabilmektedir (Tarikci, 2015, s. 131).

- MIDI kaydı (MIDI Recording): Sanal ya da gerçek MIDI enstrümanlarıyla kayıt yapılabilir. MIDI ile ses üretimi için gereken tüm olanaklar bu programlar içinde bulunmaktadır.

- MIDI Düzenleme (MIDI Editing): Yapılan MIDI kaydı veya farklı ortamlardan alınmış hazır kayıtlarla her türlü çalışma imkanı sunulmaktadır. MIDI teknolojisinin müzisyenlere sunduğu her imkan DAW olarak adlandırılan bu programlarda kullanılabilir.

- Otomatik Perde ve Ritim Düzeltme: Bu özellik ile performans esnasında yapılmış olan hatalar düzeltilebilir (Tarikci, 2015, s. 131).

\footnotetext{
${ }^{1}$ Miks: Prodüksiyonda tüm öğelerin bir araya getirildiği frekans efekt gibi özelliklerin dengeli hale getirilerek düzenlediği kayıt zincirindeki son halkadır (Önen, 2013, s. 304).

${ }^{2}$ Mastering: Ses prodüksiyonların tüketiciye ulaşmadan önce, duysal olarak daha iyi ve etkileyici kondisyona getirildiği son adımdır (Kazak, 2016, s. 2).
} 
- Nota Yazma (Scoring): Nota yazım programları kadar geniş imkanlar sunmasa da genel seviyede nota yazılabilir, MIDI veya sanal enstrüman ile yapılan işlemler notaya dönüştürülebilir, yapılan çalışma çıktı olarak alınabilir.

Ses kayıt ve düzenleme programları genel olarak benzer özelliklere sahiptir. Fiyat-performans, kullanma alışkanlığı, donanım olanakları, çalışma amacı farklılıkları gibi sebeplerle tercih edilebilecek birçok çeşidi bulunmaktadır. Bir müzik öğreticisinin bu programlarla ilgili kullanım alanları şöyle sıralanabilir;

- Tek sesli bir eseri çok sesli hale getirebilir,

- Öğreteceği eserler için altyapılar hazırlayabilir,

- Çalg1 veya şan eserleri için eşlik partileri yazabilir,

- Var olan notaları MIDI kanalıyla program içine alarak güzelleştirerek çaldırabilir,

- Canlı olarak ulaşamadığı enstrüman ve ritm çeşitliliğini sınıf içinde kolayca kullanabilir

- Koro eserleri için kayıtlar yapabilir,

- Öğrencilerin seviyesine göre konuyla ilgili öğretici kayıtlar yapabilir,

- Hazırladığı kayıtları video veya resim görselleri ile düzenleyebilir,

- Öğrencilerin derste ki performanslarını kaydedebilir,

- Eser oluşturma aşamalarına öğrencileri de dahil ederek yaratıcılıklarını geliştirebilir.

Gelişen ve çeşitlenen müzik yazılımlarının çeşitli hedefler doğrultusunda müzik sınıflarında kullanılmasının öğrencilerin motivasyonlarını, kavrama düzeylerini ve kalıcılığı sağlama düzeylerini artırdığı bilinmektedir (Çevik \& Alkan, 2012; Juntunen, Ruokonen \& Ruismäki, 2015; Şen, 2011). Ses kayıt ve düzenleme programlarının da zengin içerikleri sayesinde, günümüz müzik sınıflarında kapsamlı bir materyal geliştirme aracı olarak yararlı olacağı düşünülmektedir.

\subsection{Amac}

Bu araştırmada, en işlevsel müzik yazılımlarından olan ses kayıt ve düzenleme programlarının, sınıf ortamlarında kullanılabilecek müzik materyali geliştirme aracı olarak kullanılmaları fikrine, müzik öğretmeni adaylarının ne derece katılım gösterdikleri tespit edilmeye çalışılmıştır. Araştırmanın amacına bağlı olarak şu sorulara cevap aranmıştır:

- Müzik öğretmeni adaylarının ses kayıt ve düzenleme programlarının öğretim materyali geliştirme aracı olarak kullanılmasına yönelik görüşleri nasıl bir dağılım göstermektedir?

- Müzik öğretmeni adaylarının öğretim materyali geliştirme aracı olarak ses kayıt ve düzenleme programlarının kullanılmasına yönelik görüşleri, cinsiyetlerine, sınıf düzeylerine, bireysel çalgı türlerine ve en sevdikleri müzik türüne göre farklılık göstermekte midir?

\section{Yöntem}

\subsection{Araştırmanın Modeli}

Bu araştırmada nicel araştırma türlerinden tarama modeli kullanılmıştır. "Tarama modelleri, geçmişte ya da halen varolan bir durumu varolduğu şekliyle betimlemeyi amaçlayan araştırma yaklaşımlarıdır” (Karasar, 2014, s. 79). Büyüköztürk, Çakmak, Akgün, Karadeniz \& Demirel (2016) ise tarama modelini, "bir konuya ya da olaya ilişkin katılımcıların görüşlerinin ya da ilgi, beceri, yetenek, tutum vb. özelliklerinin belirlendiği genellikle diğer araştırmalara göre görece daha büyük örneklemler üzerinde yapılan araştırmalar” (s. 177) olarak tanımlamışlardır.

\section{2. Çalışma Grubu}

Bu araştırmanın çalışma grubunu, 2016-2017 eğitim öğretim yılında Atatürk Üniversitesi Müzik Eğitimi Anabilim Dalı, Gazi Üniversitesi Müzik Eğitimi Anabilim Dalı ve İnönü Üniversitesi Müzik Eğitimi Anabilim Dalında öğrenimine devam eden lisans öğrencileri oluşturmaktadır. Çalışma grubu seçimi için maliyet ve ulaşılabilirlik faktörleri göz önüne alınmış ayrıca seçilen müzik eğitimi anabilim dallarında kayıtlı bütün öğrencilere ulaşılması hedeflenmiştir. Hedeflenen çalışma grubuna göre ulaşılabilen öğrenci sayılarına ait bilgiler Tablo 1'de verilmiştir.

Tablo 1

Hedeflenen-ulaşılan öğrenci sayıları

\begin{tabular}{lccc}
\hline Üniversite & Kayıtlı öğrenci & Ulaşılan öğrenci & \% \\
\hline Gazi Üniversitesi & 229 & 134 & 58.5 \\
Atatürk Üniversitesi & 149 & 67 & 44.9 \\
İnönü Üniversitesi & 121 & 81 & 66.9 \\
Toplam & $\mathbf{4 9 9}$ & $\mathbf{2 8 2}$ & $\mathbf{6 2 . 8}$ \\
\hline
\end{tabular}

Tablo 1'de görüldüğü üzere 2016-2017 eğitim öğretim yılında seçilen üniversitelerin müzik eğitimi anabilim dallarına kayıtlı öğrencilerden (YÖK), \%62.8'ine ulaşılmıştır. 
Tablo 2

Araştırmanın çalışma grubu

\begin{tabular}{|c|c|c|c|}
\hline & Grup & $\mathrm{f}$ & $\%$ \\
\hline \multirow{3}{*}{ Üniversite } & Gazi Üniversitesi & 134 & 47.5 \\
\hline & İnönü Üniversitesi & 81 & 28.7 \\
\hline & Atatürk Üniversitesi & 67 & 23.8 \\
\hline \multirow{3}{*}{ Cinsiyet } & Kadın & 156 & 55.3 \\
\hline & Erkek & 126 & 44.7 \\
\hline & 1 & 32 & 11.3 \\
\hline \multirow{3}{*}{ Sinif } & 2 & 66 & 23.4 \\
\hline & 3 & 98 & 34.8 \\
\hline & 4 & 86 & 30.5 \\
\hline \multirow{3}{*}{ Bireysel çalgı türü } & Batı Müziği & 178 & 63.1 \\
\hline & Türk Müziği & 104 & 36.9 \\
\hline & Popüler Müzikler & 98 & 35.1 \\
\hline \multirow{3}{*}{ En sevdiği müzik türü } & Klasik Batı Müziği & 78 & 27.7 \\
\hline & Türk Sanat Müziği & 54 & 19.1 \\
\hline & Türk Halk Müziği & 52 & 18.1 \\
\hline
\end{tabular}

Tablo 2'de, ulaşılabilen ve olumlu yanıt verip çalışmaya katılarak çalışma grubunu oluşturan 282 müzik eğitimi anabilim dalı öğrencisine ait üniversite bilgileri ve araştırma sorularına göre belirlenen değişkenlere ait bilgiler verilmiștir.

\subsection{Verilerin Toplanması}

Araştırmanın alt problemlerinin istatistiksel analizi için gerekli verileri toplamak amacıyla araştırmacılar tarafından bir ölçek geliştirilmiştir. Veri toplama aracı iki bölümden oluşmaktadır. Birinci bölümde araştırmaya katılan öğrencilerin cinsiyet, sınıf, bireysel çalgı türü ve en sevdikleri müzik türü gibi demografik özelliklerini belirlemeye yönelik 4 adet olgusal soru; ikinci bölümünde ise müzik öğretmeni adaylarının ses kayıt ve düzenleme programlarının müzik öğretim materyali geliştirme aracı olarak kullanılmasına yönelik görüşlerini belirlemeye yönelik 25 adet yargısal soru yer almaktadır. Veri toplama aracı beşli likert tipi dereceleme türünde hazırlanmıştır. Ölçekte kullanılan dereceleme "Hiç Katılmıyorum = 1", "Çok Az Katılıyorum = 2", "Kısmen Katılıyorum = 3", "Büyük Ölçüde Katılıyorum = 4", "Tamamen Katılıyorum = 5” şeklinde oluşturulmuştur.

Yapılan literatür taraması sonucunda 42 sorudan oluşan taslak ölçme aracı hazırlanmıştır. Hazırlanan taslak ölçme aracı kapsam geçerliliği ve dil, anlatım uygunluğu için 3 alan uzmanı tarafından incelenmiştir. Alan uzmanlarının yaptığı incelemeler sonunda 10 soru ölçme aracından çıkartılmış, 3 soru ise görüşler doğrultusunda yeniden düzenlenmiştir. İnceleme ve düzeltmelerden sonra ölçme aracında 32 soruya yer verilmiştir.

Ölçme aracının geçerlilik ve güvenilirlik çalışması için, araştırma kapsamının dışında tutulan 19 Mayıs Üniversitesi Müzik Eğitimi Anabilim Dalında ön uygulama çalışması yapılmıştır.

Tablo 3

Ön uygulama grubu

\begin{tabular}{lccc}
\hline & Grup & f & $\%$ \\
\hline \multirow{2}{*}{ Cinsiyet } & Kadin & 40 & 69 \\
& Erkek & 18 & 31 \\
Sinif & 2 & 22 & 37.9 \\
& 3 & 20 & 34.5 \\
\end{tabular}

Tablo 3'te görüldüğü gibi ön uygulama çalışmasına 58 müzik öğretmeni adayı katılmıştır. Yapılan faktör analizi sonucunda 7 soru ölçme aracından çıkartılmış, 4 faktörden ve 25 sorudan oluşan ölçme aracına son şekli verilmiştir. Maddelerin faktörlerdeki yük değerleri birinci faktör için 0.537-0.813 arasında, ikinci faktör için 0.850-0.902 arasında, üçüncü faktör için 0.637-0.855 ve dördüncü faktör için 0.776-0.828 arasında değişmektedir. Faktör analizi sonucunda isimlendirme işlemi şu şekilde yapılmıştır;

- Faktör 1 - Ses kayıt ve düzenleme (SKD) programlarının kullanımı.

- Faktör 2 - Materyal kullanımı.

- Faktör 3 - SKD programlarına yönelik görüş.

- Faktör 4 - Teknoloji kullanımı.

Veri toplama aracının iç tutarlılığını incelemek ve güvenilirlik kanıtını ortaya koymak için Cronbach Alpha iç tutarlılık katsayısı hesaplanmıştır. Ölçeğin Cronbach Alpha güvenirlik katsayısı 0.920 olarak bulunmuştur. 


\subsection{Verilerin Analizi}

Verilerin çözümlenmesi, SPSS (Statistical Package for the Social Sciences) 21 paket programı ile yapılmıştır. Yapılan tüm analizlerde anlamlılık düzeyi 0.05 olarak alınmıştır. Hangi tür istatistiksel testlerin yapılacağına karar vermek için çarpıklık (Skewness), basıklık (Kurtosis) değerlerine bakılarak normallik kontrolü yapılmış ayrıca normallik testi yapılmışıtır. "Çarpıklık katsayısını ve basıklık katsayısını, sırasıyla, çarpıklığın ve basıklığın standart hatasına bölündüğ̈̈nde, çıkan değerler -1.96 ile +1.96 arasında kalıyorsa, dağılımı normal olarak kabul edilir" (Can, 2016, s. 85). Çarpıklık (Skewness), basıklık (Kurtosis) değerlerinin kendi standart hatalarına oranları sırasıyla $-1.75,-1.05$ olarak bulunmuştur. Bu değerlerin normallik varsayımını desteklediği söylenebilir.

Normallik testi için, grup büyüklüğünün 50'den az olduğu durumlarda Shapiro-Wilk, fazla olduğu durumlarda ise Kolmogov-Smirnov testi kullanılmaktadır. "Analizde istatistiksel hipotez "puanların dağılımı normal dağılımdan anlamlı farklılık göstermez" olarak kurulduğu için hesaplanan p değerinin 0.05 'den büyük çıkması, bu anlamlılık düzeyinde puanların normal dağıldığını göstermektedir” (Büyüköztürk, 2016, s. 42). Yapılan Kolmogov-Smirnov normallik testi sonucunda (p) değeri 0.51 olarak hesaplanmıştır. Bu sonuca göre "normal dağılımla aralarında fark yoktur" şeklindeki yokluk hipotezi kabul edilerek yapılan çalışmadaki verilerin normal dağılım gösterdiği kabul edilerek araştırma için yapılan istatistiksel incelemelerde parametrik testler kullanılmıştır.

"Birbiriyle ilişkisiz iki örnekleme ait ortalamalar arasındaki farkın istatistiksel olarak anlamlılı̆ı test edilmek istendiğinde Bağımsız örneklemler için t Testi" (Kilmen, 2015, s. 138); "ikiden fazla grubun ortalamaları arasındaki farkların kontrolü içinse Tek Yönlü Varyans Analizi (ANOVA)" (Can, 2016, s. 147) kullanılmaktadır. Buna göre; cinsiyet ve bireysel çalgı türü bağımsız değişkenlerine göre yapılan inceleme için t Testi; sınıf ve en sevdikleri müzik türü değişkenlerine göre yapılan inceleme için Tek Yönlü Varyans Analizi kullanılmıştır. "Tek yönlü varyans analizinde en az iki grup arasında bulunan anlamlı bir farkın hangi gruplar arasında olduğunun bulunması için çoklu karşılaştırma testleri (post-hoc test) kullanılır” (Büyüköztürk, 2016, s. 49). Tek yönlü varyans analizinin koşullarından birisi homojenliğin sağlanmasıdır. Bu koşulun gerçekleşip gerçekleşmediğinin sınamak için Levene Testi yapılmaktadır. Levene testi ile bu koşul gerçekleşmediğinde tek yönlü varyans analizi sonucu ile ilgili yorum yapabilmek için bu koşulları gerektirmeyen güçlü (robust) testler olan Brown-Forsythe veya Welch testleri kullanılmaktadır (Can, 2016; Kilmen, 2015). "Grup varyanslarının eşit olduğu varsayımı karşılandığında, gruplardaki örneklem sayıları arasında fark varsa Scheffe testi tercih edilir" (Sipahi, Yurtkoru \& Çinko'dan aktaran Can, 2016, s. 152); "grup varyanslarının eşit olmadığı durumlarda kullanılan testler arasında en güçlüsü ise GamesHowell testidir" (Field'den aktaran Kilmen, 2015, s. 143). Levene testi yapılarak varyansların eşit dağılıp dağılmadığı sorgulanmış buna göre, anlamlı farkların belirlenmesi amacıyla eşit dağılıış varyanslar için Scheffe, eşit dağılım göstermemiş varyanslar için Games-Howell çoklu karşılaştırma testi yapılmıştır. "Yapılan ANOVA testi karşılaştırılan ortalamalar arasındaki anlamlı farkı ortaya koyar fakat büyüklüğü hakkında bilgi vermez. Bu nedenle etki büyüklüğünün hesaplanması gerekir. Etki büyüklüğü eta-kare $\left(\eta^{2}\right)$, gruplar arası varyansın toplam varyansa bölünmesiyle bulunur ve 0-1 arasında bir değer alabilir" (Can, 2016, s. 157). Bu sebeple tek yönlü varyans analizi testlerinden elde edilen farkların etki büyüklükleri de hesaplanmıştır.

\section{Bulgular}

Müzik öğretmeni adaylarının, ses kayıt ve düzenleme programlarının öğretim materyali geliştirme aracı olarak kullanılmasına yönelik görüşlerinin nasıl bir dağılım gösterdiğini belirlemek amacıyla yapılan faktörlere ait elde edilen aritmetik ortalama ve standart sapma değerleri hesaplanarak Tablo 4'te gösterilmiştir.

Tablo 4

Faktörlere ait veriler

\begin{tabular}{lcc}
\hline Faktör & $\bar{x}$ & $\mathrm{~S}$ \\
\hline Ses Kayıt ve Düzenleme Programlarının Kullanılması & 4.12 & .477 \\
Materyal Kullanımı & 4.42 & .542 \\
Ses Kayıt ve Düzenleme Programlarına Yönelik Görüş & 4.10 & .584 \\
Teknoloji Kullanımı & 4.23 & .527 \\
Toplam & 4.17 & .401 \\
\hline
\end{tabular}

Tablo 4'te görüldüğü üzere verilen cevapların genel ortalaması $\bar{\chi}=4.17$ olarak ölçülmüş ve elde edilen değerlerin birbirine yakın olduğu $(S=0.401)$ tespit edilmiştir. En yüksek ortalama müzik öğretiminde materyal kullanımı faktöründe $(\bar{x}=4.42)$ ve en düşük ortalama ise ses kayıt ve düzenleme programlarına yönelik görüş faktörüne aittir $(\bar{x}=4.10)$. Faktörlere ait ortalama değerlerin hepsinin yüksek seviyede olması $(\bar{x}>4.00)$, düşük veya orta dereceli bir ortalamaya rastlanılmaması sebebiyle, ölçme aracına ait görüşlerin olumlu olduğu sonucuna varılabilir.

Öğrencilerin ses kayıt ve düzenleme programlarının öğretim materyali geliştirme aracı olarak kullanılmasına yönelik görüşlerinin cinsiyete göre farklılık gösterip göstermediğine ilişkin $t$ testi sonuçları Tablo 5 'te verilmiştir. 
Tablo 5

Cinsiyete göre $t$ testi sonuçları

\begin{tabular}{|c|c|c|c|c|c|c|}
\hline Faktörler & Cinsiyet & $\mathrm{N}$ & $\bar{x}$ & $\mathrm{Sd}$ & $\mathrm{t}$ & $\mathrm{p}$ \\
\hline SKD Programları Kullanımı & Kadın & 156 & 4.17 & 280 & 1.77 & .07 \\
\hline & Kadın & 156 & 4.51 & & & \\
\hline Materyal Kullanımı & Erkek & 126 & 4.31 & 280 & 3.19 & .00 \\
\hline SKD Programlarına Yönelik Görüş & $\begin{array}{l}\text { Kadın } \\
\text { Erkek }\end{array}$ & $\begin{array}{l}156 \\
126\end{array}$ & $\begin{array}{l}4.07 \\
4.13\end{array}$ & 280 & -.87 & .38 \\
\hline Teknoloji Kullanımı & $\begin{array}{l}\text { Kadın } \\
\text { Erkek }\end{array}$ & $\begin{array}{l}156 \\
126\end{array}$ & $\begin{array}{l}4.24 \\
4.22\end{array}$ & 280 & .27 & .78 \\
\hline Genel Ortalama & $\begin{array}{l}\text { Kadın } \\
\text { Erkek }\end{array}$ & $\begin{array}{l}156 \\
126\end{array}$ & $\begin{array}{l}4.22 \\
4.14 \\
\end{array}$ & 280 & 1.64 & .10 \\
\hline
\end{tabular}

Tablo 5 incelendiğinde öğrenci görüşlerinin cinsiyete göre anlamlı bir farklılık göstermediği görülmektedir $[\mathrm{t}(280)=1.64, \mathrm{p}>0.05]$. Kadın öğrencilerin görüşlerinin ortalaması $(\bar{x}=4.22)$ ile erkek öğrencilerin görüşlerinin ortalama değerleri $(\bar{x}=4.14)$ istatistiksel olarak anlamlı farklılaşmamaktadır.

Öğrenci görüşlerinin, sınıf düzeyleri değişkenine ait verileri Tablo 6'da ve tek yönlü varyans analizi testi sonuçları Tablo 6'da verilmiştir.

Tablo 6

Sınıf değişkenine ait veriler

\begin{tabular}{lccc}
\hline Sinif & N & $\%$ & $\bar{x}$ \\
\hline 1 & 32 & 11.3 & 3.83 \\
2 & 66 & 23.4 & 3.84 \\
3 & 98 & 34.8 & 4.36 \\
4 & 86 & 30.5 & $\mathbf{4 . 3 9}$ \\
Toplam & 282 & 100 & 4.18 \\
\hline
\end{tabular}

Tablo 6'ya göre araştırmaya 1. sınıfta okuyan 32; 2. sınıfta okuyan 66; 3. sınıfta okuyan 98 ve 4. sinıfta okuyan 86 olmak üzere toplam 282 öğrenci katılmıştır. Ses kayıt ve düzenleme programlarının öğretim materyali geliştirme aracı olarak kullanılmasına yönelik görüşlerin, sınıf değişkenine göre ortalamalarına bakıldığında, 4.sınıf öğrencilerinin $\bar{x}=4.39$ (en yüksek), 3.sınıf öğrencilerinin $\bar{x}=4.36,2$.sınıf öğrencilerinin $\bar{x}=3.84,1$.sınıf öğrencilerinin $\bar{x}=3.83$ (en düşük) ortalamaya sahip olduğu gözükmektedir.

Tablo 7

Sınıf değişkenine göre tek yönlü varyans analizi sonuçları

\begin{tabular}{llcccccc}
\hline & Varyansın Kaynağ 1 & KT & Sd & KT & F & p \\
\hline \multirow{3}{*}{ Sinıf } & Gruplar Arası & 18.675 & 3 & 6.225 & \multirow{2}{*}{ Fark } & \\
& Gruplar İçi & 26.731 & 278 & .09 & 69.166 & $\mathbf{. 0 0 0}$ & $\mathbf{4 , 3 - 2 , 1}$ \\
& Toplam & 45.405 & 281 & & & \\
\hline
\end{tabular}

Sınıf değişkenine ait varyansların homojen dağılımının ölçülmesi için yapılan Levene testinde, homojenliğin sağlandığ1 belirlenmiş (Levene değeri $=.718, \mathrm{p}>0.05$ ) ve tek yönlü varyans analizi yapılmıştır. Tablo 7 incelendiğinde, araştırmaya katılan öğretmen adaylarının görüşlerinin, sınıf değişkenine göre anlamlı bir farklılık gösterdiği görülmektedir $(\mathrm{F}=69.166, \mathrm{p}<0.05)$. Bu sonuca göre, müzik öğretiminde ses kayıt ve düzenleme programlarının kullanımına ilişkin görüşlerin sınıf değişkenine göre farklılaştığı söylenebilir. Oluşan bu farklılığın hangi sınıflar arasında olduğunu belirlemek için Scheffe çoklu karşılaştırma testi yapılmıştır.

Tablo 8

Sınıf değişkenine göre homojen alt gruplar tablosu

\begin{tabular}{lllcc}
\hline & Sinif & N & 1. grup & 2. grup \\
\cline { 2 - 5 } Scheffe & 1. sinif & 32 & $\mathbf{3 . 8 3}$ & \\
& 2. sinif & 66 & $\mathbf{3 . 8 4}$ & $\mathbf{4 . 3 3}$ \\
& 3. sinif & 98 & & $\mathbf{4 . 3 9}$ \\
& 4. sinif & 86 & $\mathbf{. 9 9 8}$ & $\mathbf{9 5 3}$ \\
\hline
\end{tabular}

Tablo 8 incelendiğinde çoklu karşılaştırmaya ilişkin homojen alt gruplar tablosunda, aralarında fark olmayan benzeşik gruplar görülmektedir. Buna göre 1. ve 2.sınıflar benzeşik bir grubu, 3. ve 4. sınıflar benzeşik diğer bir grubu oluşturmaktadır. Yapılan Scheffe çoklu karşılaştırma test sonuçları ve puan ortalamaları incelendiğinde, 4. ve 3.sınıf öğrencilerinin, 2. ve 1.sınıf öğrencilerine göre daha olumlu bir yargı içinde oldukları söylenebilir. Test sonucu hesaplanan etki büyüklüğü $(\eta 2=0.41)$ bu farkın geniş düzeyde olduğunu göstermektedir. Öğrencilerin sınıf düzeyleri arttıkça, görüşlerinin de olumlu yönde farklılaştığı söylenebilir. 
Öğrencilerin ses kayıt ve düzenleme programlarının öğretim materyali geliştirme aracı olarak kullanılmasına yönelik görüşlerinin bireysel çalgı türlerine göre farklılık gösterip göstermediğine ilişkin t testi sonuçları Tablo 9'da verilmiştir.

Tablo 9

Bireysel çalgı dersine yönelik t testi sonuçları

\begin{tabular}{|c|c|c|c|c|c|c|}
\hline Faktörler & Bireysel Çalgı Türü & $\mathrm{N}$ & $\overline{\bar{x}}$ & $\mathrm{Sd}$ & $\mathrm{t}$ & $\mathrm{p}$ \\
\hline SKD Programları & Türk Müziği & 104 & 3.92 & \multirow[b]{2}{*}{280} & \multirow{2}{*}{-5.744} & \multirow{2}{*}{.00} \\
\hline Kullanımı & Bat1 Müziği & 178 & 4.24 & & & \\
\hline & Türk Müziği & 104 & 4.36 & \multirow{2}{*}{280} & \multirow{2}{*}{-1.44} & \multirow{2}{*}{.14} \\
\hline Materyal Kullanımı & Batı Müziği & 178 & 4.46 & & & \\
\hline SKD Programlarına & Türk Müziği & 104 & 3.89 & \multirow{2}{*}{280} & \multirow{2}{*}{-4.714} & \multirow{2}{*}{.00} \\
\hline Yönelik Görüş & Batı Müziği & 178 & 4.22 & & & \\
\hline \multirow{2}{*}{ Teknoloji Kullanımı } & Türk Müziği & 104 & 3.98 & \multirow{2}{*}{280} & \multirow{2}{*}{-6.498} & \multirow{2}{*}{.00} \\
\hline & Batı Müziği & 178 & 4.38 & & & \\
\hline \multirow{2}{*}{ Genel Ortalama } & Türk Müziği & 104 & 4.00 & \multirow{2}{*}{280} & \multirow{2}{*}{-6.425} & \multirow{2}{*}{.00} \\
\hline & Batı Müziği & 178 & 4.29 & & & \\
\hline
\end{tabular}

Tablo 9 incelendiğinde, öğrenci görüşlerinin bireysel çalgı türlerine göre anlamlı bir farklılık gösterdiği görülmektedir $\left[\mathrm{t}_{(280)}=-6.425, \mathrm{p}<0.05\right]$. Bireysel çalg1 türü Batı Müziği olan öğrencilerin görüşlerinin ortalamas1 $(\bar{x}=4.29)$ ile bireysel çalgı türü Türk Müziği olan öğrencilerin görüşlerinin ortalama değerleri $(\bar{x}=4.00)$ istatistiksel olarak anlamlı farklılaşmaktadır. Buna göre, Batı Müziği enstrümanı çalan öğrencilerin Türk Müziği enstrümanı çalan öğrencilere göre, materyal geliştirmede ses kayıt ve düzenleme programlarının kullanımına yönelik görüşlerinin daha olumlu yönde olduğu söylenebilir.

Öğrencilerin ses kayıt ve düzenleme programlarının öğretim materyali geliştirme aracı olarak kullanılmasına yönelik görüşlerinin en sevdikleri müzik türü değişkenine ait verileri Tablo 10 'da ve tek yönlü varyans analizi sonuçları ise Tablo 11'de verilmiştir.

Tablo 10

En sevilen müzik türüne ait veriler

\begin{tabular}{|c|c|c|c|}
\hline Tür & $\mathrm{N}$ & $\%$ & $\overline{\bar{x}}$ \\
\hline Popüler Müzikler & 98 & 35.1 & 4.36 \\
\hline Klasik Batı Müziği & 78 & 27.7 & 4.19 \\
\hline Türk Sanat Müziği & 54 & 19.1 & 4.05 \\
\hline Türk Halk Müziği & 52 & 18.1 & 4.00 \\
\hline Toplam & 282 & 100 & 4.18 \\
\hline
\end{tabular}

Tablo 10 incelendiğinde, Popüler Müzikler olarak işaretlenmiş cevapların en yüksek ortalamaya $(\bar{x}=4.36)$, Türk Sanat Müziği olarak işaretlenmiş cevapların ise en düşük ortalamaya ( $\bar{x}=4.00)$ sahip olduğu gözükmektedir. Popüler müzik dinlediğini söyleyen öğrencilerin örneklemdeki oranı yüksektir. Aynı zamanda, ölçek ortalamaları en yüksek olanlar da popüler müzik dinlemeyi tercih edenlerdir.

Tablo 11

En sevilen müzik türüne ait tek yönlü varyans analizi sonuçları

\begin{tabular}{llcccccc}
\hline & Varyansın Kaynağı & KT & Sd & KT & F & p & Fark \\
\hline \multirow{3}{*}{ En Sevilen Müzik Türü } & Gruplar Arası & 5.706 & 3 & 1.902 & & \\
& Gruplar İçi & 39.699 & 278 & .142 & 13.394 & $\mathbf{. 0 0 0}$ & \multirow{2}{*}{ Popüler-Diğer } \\
& Toplam & 45.405 & 281 & & & & \\
\hline
\end{tabular}

En sevilen müzik türü değişkenine ait varyansların homojen dağılımının ölçülmesi için yapılan Levene testinde, homojenliğin sağlanamadığı belirlenmiştir (Levene değeri=3.590, $\mathrm{p}<0.05$ ). Varyansların eşitliği koşulu sağlanamadığında bu koşul olmadan karar verilmesine olanak veren güçlü testler yapılabilmektedir (Can, 2016; Kilmen, 2015). Buna göre yapılan Browne-Forsythe $(0.62, \mathrm{p}>0.05)$ ve Welch $(0.52, \mathrm{p}>0.05)$ testlerin sonucuna göre tek yönlü varyans analizi yapılmıştır. Tablo 11 incelendiğinde, öğretmen adaylarının görüşlerinin, en sevilen müzik türü değişkenine göre anlamlı bir farklılık gösterdiği görülmektedir $(F=13.394, p<0.05)$. Bu sonuca göre, materyal geliştirmede ses kayıt ve düzenleme programlarının kullanımına ilişkin görüşlerin en sevilen müzik türü değişkenine göre farklılaştığı söylenebilir. Oluşan farklılığın hangi müzik türleri arasında olduğunu belirlemek için Games-Howell çoklu karşılaştırma testi yapılmıştır.

Tablo 10 ve Tablo 11 incelendiğinde, Popüler Müzikler ile Klasik Batı Müziği, Türk Sanat Müziği ve Türk Halk Müziği arasında, Popüler Müzikler lehine istatistiksel olarak anlamlı fark bulunmuştur. Test sonucu hesaplanan etki büyüklüğ̈̈ $(\eta 2=0.12)$ bu farkın orta düzeyde olduğunu göstermektedir. Öğrencilerin en sevdikleri müzik türleri ile materyal geliştirmede ses kayıt ve düzenleme programlarının kullanımına yönelik görüşleri arasında, Popüler Müzikler lehine olmak üzere istatistiksel olarak anlamlı bir ilişki olduğu söylenebilir. 


\section{Sonuç ve Tartışma}

Araştırmanın ilk alt problemi "Müzik öğretmeni adaylarının ses kayıt ve düzenleme programlarının öğretim materyali geliştirme aracı olarak kullanılmasına yönelik görüşleri nasıl bir dağılım göstermektedir?” olarak oluşturulmuştur.

İlk alt problemin çözümüne yönelik yapılan analiz sonuçlarına bakıldığında, müzik öğretmeni adaylarının, materyal geliştirmede ses kayıt ve düzenleme programlarının kullanılması görüşüne yüksek oranda ve olumlu yönde katıldıkları sonucuna ulaşılmıştır. Bu sonuç, müzik eğitiminde teknoloji kullanımı başlığı altında değerlendirildiğinde Çevik \& Alkan (2012), Juntunen, Ruokonen \& Ruismäki (2015), Koç (2004), Koldemir (2008), Lehimler (2012), Okay (2016), Rowe, Triantafyllaki \& Anagnostopoulou (2015), Şen (2011), Yengin (2014) tarafından elde edilen sonuçlarla benzerlikler göstermektedir. Buna göre, müzik dünyasında sunduğu olanaklarla büyük kolaylıklar ve yenilikler getiren ses kayıt ve düzenleme programlarının müzik sınıflarında kullanılması müzik öğretmeni adaylarının görüşlerine göre faydalı olacaktır.

Elde edilen sonuç faktörler boyutunda incelendiğinde, "ses kayıt ve düzenleme programları kullanımı" boyutuna yönelik cevaplarının büyük oranda olumlu olduğu sonucuna ulaşılmıștır. Buna göre öğretmen adayları ses kayıt ve düzenleme programlarını kullanmaktalardır. Müzik öğretmeni adaylarının "materyal kullanımı" boyutuna yüksek oranda ve olumlu yönde katılım göstermişlerdir. Bu görüş Bilgi (2002), Dalmışlı (2013), Keleş (2007), Kahraman (2010), Şen (2011), Verim (2013), Yılmaz (2014) tarafından elde edilen sonuçları destekler niteliktedir. Yapılmış olan bu çalışmalarda öğretim materyallerinin eğitim-öğretim süreçlerine olumlu yönde katkısı olduğu sonuçlarına varılmıştır. Müzik öğretmeni adaylarının "ses kayıt ve düzenleme programlarına yönelik görüş" boyutuna yüksek oranda ve olumlu yönde katıldıkları sonucuna varılmıştır. Bu sonuca göre müzisyenler arasında kullanım sıklığı her geçen gün artan bu programlar, müzik öğretmeni adayları tarafindan da faydalı programlar olarak görülerek benimsenmiş durumdadır. Müzik öğretmeni adaylarının “teknoloji kullanımı” boyutuna yönelik görüşlerinin yüksek oranda ve olumlu yönde olduğu sonucuna varılmıştır. Çoklar (2008), Tas (2011), Khurmyet (2016), Mert \& Şen (2019), Seçkin Kapucu (2014) yaptıkları çalışmalarda öğretim aşamasında teknoloji kullanımının yararlarını vurgulamışlardır. Müzik öğretmeni adaylarından teknoloji kullanımı boyutuna yönelik elde edilen sonuçta yapılmış olan çalışmalarla paralellik göstermektedir.

Araştırmanın ikinci alt problemi "Müzik öğretmeni adaylarının öğretim materyali geliştirme aracı olarak ses kayıt ve düzenleme programlarının kullanılmasına yönelik görüşleri, cinsiyetlerine, sınıf düzeylerine, bireysel çalgı türlerine ve en sevdikleri müzik türüne göre farklılık göstermekte midir?” olarak oluşturulmuştur.

Müzik öğretmeni adaylarının görüşlerinin cinsiyetlerine göre farklılık gösterip göstermediğine yönelik yapılan analizler sonucunda anlamlı bir farklılığın oluşmadığı sonucu bulunmuştur. Yapılan incelemede aynı konunun araştırıldığı başka bir çalışmaya rastlanılmamıştır. Bununla beraber teknoloji liderliği yeterliği alanında Görgülü, Küçükali \& Ada (2013), Çakır \& Aktay (2018); bilişim teknolojilerine yönelik tutum alanında Özdemir (2010); bilișim teknoloji kullanımında model olma farkındalığı incelemesinde Özüdoğru \& Çakır (2014) yaptıkları çalışmalarda cinsiyetler arası bir farkın anlamlı düzeyde olmadığı sonuçlarını elde etmişlerdir. Eğitim alanında bilişim teknolojileri genel çatısı altında düşünüldüğünde incelenen araştırmalardaki sonuçların, bu araştırmadan elde edilen sonuçları destekler nitelikte olduğu söylenebilir.

Müzik öğretmeni adaylarının görüşlerinin sınıf düzeylerine göre farklılık gösterip göstermediğine yönelik yapılan analiz sonuçlarında anlamlı farklılıklar bulunmuştur. Ölçeğin genelinde ve incelenen bütün faktörlerde, 3. ve 4.sınıf öğrencilerinin görüşleri, 1. ve 2. sınıf öğrencilerine göre pozitif yönde ve anlamlı düzeyde farklıdır. Elde edilen analiz sonuçlarına göre sınıf düzeyi arttıkça materyal geliştirmede ses kayıt ve düzenleme programlarının kullanılmasına yönelik görüşler pozitif yönde ve anlamlı şekilde artmaktadır. Aynı konunun araştırıldığı başka bir çalışma olmamakla beraber, Menzi, Çalışkan \& Çetin (2012) teknoloji yeterlilikleri, Baydaş, Uzuner Yurt \& Aktaş (2019) ise teknoloji kullanma kabul düzeylerinin sınıf seviyesiyle doğru orantılı şekilde arttı̆̆ sonucuna varmışlardır. 3. ve 4 sınıf öğrencileri aldıkları ders sayıları ve tecrübeleri bakımından 1. ve 2. sınıf öğrencilerinden daha tecrübeli durumdalardır. Özellikle öğretim teknolojileri ve materyal tasarım dersinin 3. sınıfta alınması, öğretmenlik uygulamasının 4. sınıfta olması, bu durumu açıklamaya etken faktörler olabilir.

Müzik öğretmeni adaylarının görüşlerinin bireysel çalgı türlerine göre farklılık gösterip göstermediğine yönelik yapılan analiz sonuçlarında anlamlı bir farklılığın oluştuğu görülmüştür. Buna göre, bireysel çalgı türü Batı Müziği olan öğrencilerin, bireysel çalgı türü Türk Müziği olan öğrencilere göre, materyal geliştirmede ses kayıt ve düzenleme programlarının kullanılmasına yönelik görüşleri pozitif yönde ve anlamlı düzeyde daha olumludur. Faktörler boyutunda yapılan incelemelerde materyal kullanımı ve bireysel çalgı türü arasında anlamlı bir ilişki bulunamamıştır. Diğer bütün faktörlerde Batı Müziği lehine olmak üzere pozitif yönde ve anlamlı düzeyde bir farklılık bulunmuştur. Elde edilen sonuçlara bakıldığında her iki grubun cevaplarının ortalamasının $(\bar{x} \geq 4.00)$ yüksek olduğu görülmektedir. Bireysel çalgı türü Türk Müziği olan öğrenciler de materyal geliştirmede ses kayıt ve düzenleme programlarının kullanılmasına yönelik görüşleri yüksektir. Ancak bireysel çalgı türü Batı Müziği olan öğrencilerin katılım oranı daha yüksektir. Batı toplumunda oluşturulmuş bu programların temel özellikleri 
(kayıt, kesme, yapıştırma) dışında, ulaşılabilen sanal enstrüman çeşitliliği, hazır ses bankaları ve ritm seçenekleri gibi özelliklerinin, ayrıca bu programlar için hazırlanmış eğitim videoların da genelde çok sesli tonal yapı için hazırlandığı görülmektedir. Bu sebeple arada oluşan farkın, bu programların Batı Müziği enstrümanı çalan öğrencilerin daha çok ilgisini çektiğinden kaynaklandığı düşünülebilir.

Müzik öğretmeni adaylarından toplanan veriler arasında en sevdikleri müzik türü değişkenine göre yapılan istatistiksel testler sonucunda anlamlı bir farklılığın oluştuğu görülmüştür. En sevdiği müzik türünü Popüler Müzikler olarak belirten öğrenci grubunun, diğer gruplara göre materyal geliştirmede ses kayıt ve düzenleme programlarının kullanılması görüşüne daha yüksek oranda katıldığı bulunmuştur. Ses kayıt ve düzenleme programlarının kayıt özellikleri dışında, hazır döngüler, ses bankaları, efektler gibi özelliklerinin, daha çok popüler olarak nitelendirilecek müzik türleri için olmaları, bu sonucun elde edilmesini açıklamaya yardımcı bir etken olabilir.

Araştırma sonucunda elde edilen veriler 1şı̆̆ında;

- Müzik öğretiminde bilgisayar uygulamaları gibi derslerde ses kayıt ve düzenleme programları ile ilgili eğitim verilmesi,

- Materyal geliştirme derslerinde, ses kayıt ve düzenleme programlarının kullanıldığı materyallerin hazırlanmasının teşvik edilmesi,

- Daha büyük örneklem gruplarıyla çalışmalar yapılması,

- Hizmet içinde bulunan müzik öğretmenleri ile ilgili çalışmalar yapılması,

- Deneysel yöntemin uygulanacağı çalışmalar yapılması önerilmektedir.

\section{Kaynakça}

Aslan Efe, H., \& Baysal, Y. (2017). Fen bilgisi öğretmenlerinin eğitim teknolojilerini kullanmaya yönelik motivasyon ve öz düzenleme stratejileri arasındaki ilişkinin belirlenmesi. Elektronik Sosyal Bilimler Dergisi, 16(63), 1391-1399. doi: https://doi.org/10.17755/esosder.308979

Baydaş, Ö., Uzuner Yurt, S., \& Aktaş, E. (2019). Öğretmen adaylarının gelecekteki derslerinde teknoloji kullanma kabullerinin sınıf düzeylerine ve branşlara göre farkı. Erzincan Üniversitesi Eğitim Fakültesi Dergisi, 21(1), 74-89. doi: https://doi.org/10.17556/erziefd.322663

Bilgi, A. D. (2002). Uygun olmayan davranışı, uygun davranışı ödüllendirmenin işareti olarak kullanan öğretim materyalinin ögretmen ödüllerinin arttırılmasına etkisi (Yüksek Lisans Tezi). YÖK tez veri tabanından erişildi (Tez No. 113200).

Büyüköztürk, Ş. (2016). Sosyal bilimler için veri analizi el kitabı. Ankara: Pagem Akademi.

Büyüköztürk, Ş., Çakmak, E. K., Akgün, Ö. E., Karadeniz, S., \& Demirel, F. (2016). Bilimsel araştırma yöntemleri. Ankara: Pagem.

Can, A. (2016). Spss ile bilimsel araştırma sürecinde nicel veri analizi. Ankara: Pegem Akademi.

Çakır, R., \& Aktay, S. (2018). Okul yöneticilerinin teknoloji liderliği yeterlikleri. Karadeniz Uluslararası Bilimsel Dergi, 37(37), 37-48. Erişim adresi: https://dergipark.org.tr/tr/download/article-file/446696

Çakırer, H. S. (2002). Türkiye'de müzik eğitiminde teknoloji (Doktora Tezi). YÖK tez veri tabanından erişildi (Tez No. 125801).

Çelik, M., \& Şendağ, B. A. (2013). Illköğretim müzik 6-7-8 öğretmen kılavuz kitabı. Ankara: Milli Eğitim Bakanlıği.

Çevik, B. D., \& Alkan, M. (2012). Müzik öğretmenliği bölümü öğrencilerinin teknoloji kullanımına yönelik görüşleri. Journal Of Educational And Instructional Studies In The World, 2(1), 135-141. Erişim adresi: http://www.wjeis.org/FileUpload/ds217232/File/20x.cevik.pdf

Çoklar, A. N. (2008). Öğretmen adaylarının eğitim teknolojisi standartları ile ilgili özyeterliklerinin belirlenmesi (Doktora Tezi). YÖK tez veri tabanından erişildi (Tez No. 234361).

Dalmışlı, F. (2013). Müzik eğitiminde materyal kullanımı (Yüksek Lisans Tezi). YÖK tez veri tabanından erişildi (Tez No. 406985).

Field, A. (2009). Discovering statistics using SPSS. Los Angeles: Sage Publications.

Görgülü, D., Küçükali, R., \& Ada, Ş. (2013). Okul yöneticilerinin teknolojik liderlik öz-yeterlilikleri. Eğitim Teknolojisi Kuram ve Uygulama, 3(2), 53-71. Erişim adresi: https://dergipark.org.tr/en/download/articlefile/71807 
Hırça, N., \& Genç, M. (2012). Fen eğitiminde materyal tasarımı için medya ve teknoloji. Bartın Üniversitesi Eğitim Fakültesi Dergisi, 1(1), 252-260. Erişim adresi: https://dergipark.org.tr/en/download/article-file/43558

Juntunen, P., Ruokonen, I., \& Ruismäki, H. (2015). Music behind scores: Case study of learning improvisation with playback orchestra method. Journal of Computer Assisted Learning, 31(6), 582-591. doi: https://doi.org/10.1111/jcal.12098

Kahraman, S. (2010). Atomun yapısı ve orbitaller konusunda geliştirilen üç boyutlu bilgisayar destekli öğretim materyallerinin ögretmen adaylarının başarısı ve tutumlarına etkisi (Doktora Tezi). YÖK tez veri tabanından erişildi (Tez No. 270725).

Kalelioğlu, F. (2015). Öğretim teknolojileri ve materyal tasarımı. E. Cabı (Ed.), Temel kavramlar (s. 1-14) içinde. Ankara: Pegem Akademi.

Karasar, N. (2014). Bilimsel araştırma yöntemi. Ankara: Nobel Akademik.

Kaya, Z. (2006). Öğretim teknolojileri ve materyal geliştirme. Ankara: Pagem Akademi.

Kazak, M. (2016). Mastering işleminde analog ve modelleme karşılaştırılması (Yüksek Lisans Tezi). YÖK tez veri tabanından erişildi (Tez No. 449250).

Keleş, E. (2007). Altıncı sınıf kuvvet ve hareket ünitesine yönelik beyin temelli öğrenmeye dayalı web destekli ögretim materyalinin geliştirilmesi ve etkililiğinin değerlendirilmesi (Doktora Tezi). YÖK tez veri tabanından erişildi (Tez No. 212082).

Khurmyet, G. (2016). Mobil eğitim teknolojisi olarak tablet bilgisayarın etkin ögrenim amaçlı kullanımı: Özel ortaögretim kurumları üzerine bir araştırma (Yüksek Lisans Tezi). YÖK tez veri tabanından erișildi (Tez No. 437192 ).

Kilmen, S. (2015). Eğitim araştırmacıları için SPSS uygulamalı istatistik. Ankara: Edge Akademi.

Koç, A. (Nisan, 2004). Günümüzde bilgisayar destekli yazılımların müzik eğitimine katkıları. 1924-2004 Musiki Muallim Mektebinden Günümüze Müzik Öğretmeni Yetiştirme Sempozyumu'nda sunulmuș bildiri, Süleyman Demirel Üniversitesi, Isparta. Erişim adresi: http://www.muzikegitimcileri.net/bilimsel/bildiri/ A-Koc.pdf

Koldemir, S. (2008). Anadolu güzel sanatlar liselerinde bilgisayar destekli müzik eğitiminin kullanılabilme durumu (Yüksek Lisans Tezi). YÖK tez veri tabanından erişildi (Tez No. 235004).

Lehimler, E. (2012). Müzik ögrretmeni yetiştiren kurumlarda bilgisayar derslerinde ögretilen müzik programlarının ve yazılımlarının piyano eğitimine katkılarının incelenmesi (Yüksek Lisans Tezi). YÖK tez veri tabanından erişildi (Tez No. 319643).

Lehimler, E., \& Şengül, C. (2014). Müzik yazılımlarının piyano eğitimine katkılarının incelenmesi. Atatürk Üniversitesi Sosyal Bilimler Enstitüsü Dergisi, 18(2), 229-246. Erişim adresi: https://dergipark.org.tr/tr/ pub/ataunisosbil/issue/2836/38666

Lewis, C. (1998). Teaching with technology in the college of music. University of Colorado. https://www.colorado.edu/AmStudies/collmus.htm

Menzi, N., Çalışkan, E., \& Çetin, O. (2012). Öğretmen adaylarının teknoloji yeterliliklerinin çeşitli değişkenler açısından incelenmesi. Anadolu Journal Of Educational Sciences International, 2(1), 1-18. Erişim adresi: https://dergipark.org.tr/en/pub/ajesi/issue/1526/18732

Mert, E., \& Şen, Ü. S. (2019). İlköğretim 7. sınıf müzik öğretiminde teknoloji destekli materyal kullanımının akademik başarıya etkisi. Atatürk Üniversitesi Sosyal Bilimler Enstitüsü Dergisi, 23(4) , 2113-2139. Erişim adresi: https://dergipark.org.tr/en/pub/ataunisosbil/issue/51800/553839

Okay, H. (2016). Müzik öğretmeni adaylarının nota yazım programlarının kullanımına yönelik eğilimleri (Balıkesir Üniversitesi örneği). Sakarya Üniversitesi Ĕ̆itim Fakültesi Dergisi, 31, 74-87. Erişim adresi: https://dergipark.org.tr/en/download/article-file/227564

Önen, U. (2013). Ses kayıt ve müzik teknolojileri. İstanbul: Çitlembik.

Özdemir, L. (2010). Bilişim teknolojisi tutumları farklı üniversite personelinin bilişim teknolojisi becerilerinin değerlendirilmesi. Atatürk Üniversitesi İktisadi ve İdari Bilimler Dergisi, 24(1), 113-128. Erişim adresi: https://dergipark.org.tr/tr/pub/atauniiibd/issue/2698/35572

Özüdoğru, G., \& Çakır, H. (2014). Öğretim elemanlarının bilişim teknolojileri kullanımında öğretmen adaylarına model olma farkındalıklarının incelenmesi. Ahi Evran Üniversitesi Kırşehir Ĕ̆itim Fakültesi Dergisi, 15(2), 
Rowe, V., Triantafyllaki A., \& Anagnostopoulou X. (2015). Young pianists exploring improvisation using interactive music technology. International Journal of Music Education 33(1), 113-130. doi: https://doi.org/10.1177/0255761414540137

Seçkin Kapucu, M. (2014). Fen ve teknoloji dersinde görsel medya kullanımına yönelik fen bilgisi öğretmenlerin görüşleri. Pegem Ĕ̆itim ve Öğretim Dergisi. 4(2), 75-90. doi: https://doi.org/10.14527/pegegog.2014.010

Sipahi, B., Yurtkoru, E. S., \& Çinko, M. (2008). Sosyal bilimlerde SPSS ile veri analizi. İstanbul: Beta Yayınları.

Şen, Ü. S. (2011). Müzik öğretiminde bilgisayar destekli programlı ögrretim yönteminin etkililiği (Doktora Tezi). YÖK tez veri tabanından erişildi (Tez No. 290503).

Tarikci, A. (2015). Müzik teknolojisine giriş. Ankara: Müzik Eğitimi.

Tas, Ş. (2011). Sinıf öğretmenlerinin kaynaştırma eğitiminde ĕgitim teknolojileri kullanım durumları (Yüksek Lisans Tezi). YÖK tez veri tabanından erişildi (Tez No. 291192).

Uçan, A. (1997). Müzik eğitimi: Temel kavramlar-ilkeler-yaklaşımlar. Ankara: Müzik Ansiklopedisi.

Verim, G. (2013). Ortä̈ğretim kurumlarında görev yapan öğretmenlerin öğretim teknolojileri ve materyal tasarımlarına ilişkin görüşleri (Yüksek Lisans Tezi). YÖK tez veri tabanından erişildi (Tez No. 336974).

Watson, S. (2011). Using technology to unlock musical creativity. New York: Oxford University Press.

Wise, S., Greenwood, J., \& Davis, N. (2011). Teachers' use of digital technology in secondary music education: Illustration of changing classrooms. British Journal Of Music Education, 28(2), 117-134. doi: https://doi.org/10.1017/S0265051711000039

Yengin, A. (2014). Müzik teknolojilerinin örgün müzik ĕgitiminde kullanılma durumlarına ilişkin ögretmen görüşleri: Burdur ili örneği (Yüksek Lisans Tezi). YÖK tez veri tabanından erişilldi (Tez No. 370246).

Yılmaz, E. M. (2014). Görsel sanatlar öğretmen adaylarının ilköğretim okulları ögrencilerine sanatsal düzenleme ilkelerinin ögretimine yönelik ögretim materyali tasarım süreçleri (Doktora tezi). YÖK tez veri tabanından erişildi (Tez No. 354650).

Yükseköğretim Kurumu. (t.y.). Yükseköğretim bilgi yönetim sistemi. Erişim adresi: https://istatistik.yok.gov.tr 


\section{Ek 1. Ölçme Aracı}

Bu çalışma, ses kayıt ve düzenleme programlarının müzik öğretim materyali geliştirme aracı olarak kullanılmasına yönelik düşüncelerinizi almak için hazırlanmıştır. Her ifadenin size en uygun tek bir cevabına çarpı (X) işareti koyunuz.

\begin{tabular}{|c|c|c|c|c|c|c|}
\hline \multicolumn{2}{|r|}{$\begin{array}{l}\text { Bu çalışma, ses kayıt ve düzenleme programlarının müzik öğretim materyali geliştirme } \\
\text { aracı olarak kullanılmasına yönelik düşüncelerinizi almak için hazırlanmıştır. Her ifadenin } \\
\text { size en uygun tek bir cevabına çarpı (X) işareti koyunuz. }\end{array}$} & \multirow[t]{2}{*}{ 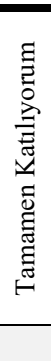 } & \multirow[t]{2}{*}{ 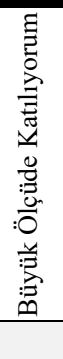 } & \multirow[t]{2}{*}{ 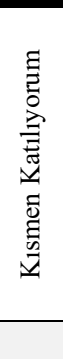 } & \multirow[t]{2}{*}{ 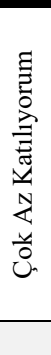 } & \multirow[t]{2}{*}{ 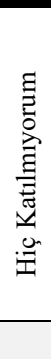 } \\
\hline 1 & Materyal kullanımı müzik öğretimi için önemlidir & & & & & \\
\hline 2 & Materyaller müzik dersini daha eğlenceli yapar & & & & & \\
\hline 3 & Materyal kullanımı derse olan ilgiyi arttırır & & & & & \\
\hline 4 & Materyal kullanımı bilginin kalıcılığını arttırır & & & & & \\
\hline 5 & Müzik öğretimi için teknoloji desteği önemlidir & & & & & \\
\hline 6 & Teknolojik materyal kullanımı pratiktir & & & & & \\
\hline 7 & Müzik öğretiminde teknoloji kullanımı yaratıcılığı geliştirir & & & & & \\
\hline 8 & $\begin{array}{l}\text { Müzik öğretiminde teknoloji kullanımı gelecekte daha önemli bir yere sahip } \\
\text { olacaktır }\end{array}$ & & & & & \\
\hline 9 & Ses kayıt ve düzenleme (skd) programları müzikle daha iç içe olmamı sağlar & & & & & \\
\hline 10 & Skd programları beni daha üretken yapar & & & & & \\
\hline 11 & Skd programları müziğe duyulan ilgiyi arttırır & & & & & \\
\hline 12 & Skd programlarına karşı hiç bir merakım yok & & & & & \\
\hline 13 & Skd programları eşlik için kullanılabilir & & & & & \\
\hline 14 & Skd programları ile üretilmiş materyaller müzik dersini daha eğlenceli yapar & & & & & \\
\hline 15 & $\begin{array}{l}\text { Skd programları ile üretilen materyallerin sürekli güncellenip değiştirilebilmesi } \\
\text { onları daha kullanışlı yapar }\end{array}$ & & & & & \\
\hline 16 & Skd programları ile materyal hazırlanmasına sıcak bakmıyorum & & & & & \\
\hline 17 & Skd programları materyal hazırlamayı kolaylaştırır & & & & & \\
\hline 18 & Skd programları materyal çeşitliliğini arttırır & & & & & \\
\hline 19 & Skd programları ile materyal hazırlamak pratik değil & & & & & \\
\hline 20 & Skd programları bir ezgiyi öğrencilerin ilgisi yönünde düzenlemeye olanak tanır & & & & & \\
\hline 21 & Skd programları müzik öğretmenleri tarafindan öğrenilmelidir & & & & & \\
\hline 22 & $\begin{array}{l}\text { Skd programları ses bankaları sayesinde ulaşılamayacak enstrümanlara ulaşmayı } \\
\text { sağlar }\end{array}$ & & & & & \\
\hline 23 & Skd programları kayıt özellikleri sayesinde kontrol amaçlı kullanılabilir & & & & & \\
\hline 24 & Skd programları ile birden fazla duyu organına hitap eden materyaller tasarlanabilir & & & & & \\
\hline 25 & Lisans eğitiminde skd programları öğretilmelidir & & & & & \\
\hline
\end{tabular}

